\title{
Aging Is Associated with a Proapoptotic Endothelial Progenitor Cell Phenotype
}

\author{
Erich J. Kushner ${ }^{a}$ Owen J. MacEneaney ${ }^{a}$ Brian R. Weil $^{a}$ Jared J. Greiner ${ }^{a}$ \\ Brian L. Stauffer ${ }^{a-c}$ Christopher A. DeSouza ${ }^{a, b}$ \\ ${ }^{a}$ Integrative Vascular Biology Laboratory, Department of Integrative Physiology, University of Colorado, \\ Boulder, Colo., ${ }^{b}$ Department of Medicine, University of Colorado Denver, Aurora, Colo., and ' Denver Health \\ Medical Center, Denver, Colo., USA
}

\section{Key Words}

Age $\cdot$ Apoptosis $\cdot$ Progenitor cells

\begin{abstract}
The aim of this study was to determine if aging is associated with enhanced endothelial progenitor cell (EPC) sensitivity to apoptosis. Cells with phenotypic EPC characteristics were isolated from healthy, nonobese young (age $25 \pm 1$ years) and older (61 \pm 1 years) men. Intracellular active caspase-3 concentrations in response to staurosporine stimulation were approximately $35 \%$ higher $(p<0.05)$ in EPCs from older $(3.15 \pm 0.29 \mathrm{pg} / \mathrm{ml})$ compared with young $(2.33 \pm 0.24 \mathrm{pg} /$ $\mathrm{ml}$ ) men. Protein expression of Akt, p70 S6-kinase and Bcl-2 was markedly lower (approx. 35, 75 and 60\%, respectively, all $p<0.05$ ) in EPCs from older compared with young men, whereas there were no age-related differences in either 143-3 $\varepsilon$ or Bax expression. Additionally, EPC telomerase activity was $57 \%$ lower $(p<0.05)$ in older $(0.18 \pm 0.11 \mathrm{AU})$ versus young $(0.43 \pm 0.11 \mathrm{AU})$ men. These results indicate that aging is associated with a proapoptotic EPC phenotype characterized by decreased expression of key antiapoptotic proteins associated with the PI-3-kinase signaling pathway and reduced telomerase activity. These age-related changes like-
\end{abstract}

ly contribute, in part, to the diminished ability of EPCs to resist an apoptotic stimulus in older men. Increased susceptibility to apoptosis may contribute to the numerical and functional impairments observed in EPCs with aging.

Copyright $\odot 2011$ S. Karger AG, Basel

\section{Introduction}

Aging is associated with deleterious modifications in the structure and function of the vasculature, such as increased carotid intima-media thickness and decreased endothelial vasomotor as well as fibrinolytic function [1-3]. Age-related alterations in the vasculature precede and predispose individuals to cardiovascular disease and its clinical sequelae (for example, arterial spasm, myocardial infarction and stroke) [1]. In addition, diminished bioavailability or functional impairments in endogenous vascular repair mechanisms, such as endothelial progenitor cells (EPCs), are thought to contribute etiologically to the manifestation of cardiovascular disease [4]. EPCs are bone marrow-derived circulating cells that are now recognized to play an important role in vascular repair and neovascularizartion [5]. Indeed, EPCs home to sites

\section{KARGER}

(c) 2011 S. Karger AG, Basel

Fax +4161306 1234

E-Mail karger@karger.ch

www.karger.com
Accessible online at:

www.karger.com/jvr
Dr. Christopher A. DeSouza

Integrative Vascular Biology Laboratory

Department of Integrative Physiology, 354 UCB

University of Colorado, Boulder, CO 80309 (USA)

Tel. +1 303492 2988, E-Mail desouzac@ colorado.edu 
of vascular injury and elicit proangiogenic, prosurvival and anti-inflammatory effects that contribute to the reparative process $[6,7]$. Moreover, EPCs can integrate into newly forming blood vessels and are able to transdifferentiate into a variety of cell phenotypes, such as mature endothelial cells and smooth muscle cells [8]. Aging is associated with reduced number and function of EPCs [9, $10]$, and this may contribute to the greater cardiovascular risk and reduced angiogenic capacity in middle-aged and older adults $[11,12]$.

Apoptosis, or programmed cell death, is a fundamental cellular program that is highly regulated to protect against aberrant cell death and/or proliferation $[13,14]$. Initiation of apoptosis, either by extracellular or internal events, triggers a hierarchy of caspases, a family of cysteine-aspartic acid proteases, leading to cell destabilization and destruction [15]. Induction of apoptosis is highly conserved in biological systems [16], and dysregulation of apoptotic programs can lead to blunted cell viability or unrestricted cell/tissue growth [14]. The phosphoinositide 3-kinase (PI-3-kinase)/Akt signaling pathway plays a key role in regulating caspase-mediated apoptosis. Activation of Akt phosphorylates the downstream protein Bad, leading to its sequestration of Bad via a 14-3-3 $\varepsilon$ complex. Nonphosphorylated Bad translocates to the mitochondria and inhibits the expression of the antiapoptotic protein $\mathrm{Bcl}-2$. Inhibition of $\mathrm{Bcl}-2$ promotes the release and activation of downstream mitochondrial-associated proapoptotic proteins, such as Bax and cytochrome-c, resulting in caspase-mediated apoptosis [15]. In addition, telomerase activity has been linked to a regulatory role in caspase signaling and apoptosis [17]. The influence of aging on EPC apoptosis is currently unknown. Increased susceptibility to apoptosis may contribute to the numerical and functional impairments observed in EPCs with age $[18,19]$ and, in turn, age-related CVD risk.

The aim of the current study was to determine if aging is associated with enhanced EPC sensitivity to apoptosis. To address this aim, we assessed active intracellular caspase- 3 concentrations and determined the expression of key PI-3-kinase/Akt pathway proteins to gain insight into signaling mechanisms that may contribute to altered apoptotic sensitivity with age.

\section{Methods}

\section{Subjects}

Peripheral blood samples were obtained from 16 young (age 21-34 years) and 23 older (age 56-67 years) healthy, sedentary men. All subjects were nonobese (BMI $\leq 30.0)$, nonsmokers, normotensive (arterial blood pressure $\leq 140 / 90 \mathrm{~mm} \mathrm{Hg}$ ), nonmedicated and free of overt cardiovascular as well as metabolic disease as assessed by medical history, physical examination and fasting blood chemistries. The older men were further evaluated for clinical evidence of coronary artery disease with electrocardiogram and blood pressure at rest and during incremental exercise performed to exhaustion. Before participation, all subjects provided written informed consent according to the guidelines of the Institutional Review Board of the University of Colorado at Boulder.

\section{EPC Isolation}

Putative EPCs were cultured as previously described by our laboratory [10]. Briefly, EPCs were isolated via Ficoll-density gradient centrifugation (Histopaque 1077; Sigma, St. Louis, Mo., USA), washed, resuspended in growth medium (Medium 199; Gibco, Grand Island, N.Y., USA), supplemented with $20 \%$ fetal calf serum, penicillin $(100 \mathrm{U} / \mathrm{ml})$ and streptomycin $(100 \mathrm{mg} / \mathrm{ml})$, and plated on human fibronectin (BD Biosciences, San Jose, Calif., USA) coated 6 -well plates for $48 \mathrm{~h}$ at $37^{\circ} \mathrm{C}$. Thereafter, nonadherent cells were collected for analysis. Endothelial phenotype of these putative EPCs was confirmed by immunofluorescent staining for the uptake of DiI-ac-LDL (Biomedical Technologies, Stoughton, Mass., USA) and expression of von Willebrand factor (Dako, Glostrup, Denmark), VE-cadherin, CD31 and VEGFR-2 (Invitrogen, Carlsbad, Calif., USA). In addition, fluorescence-activated cell-sorting analysis utilizing antibodies recognizing cell surface expression of VEGFR-2 (R\&D Systems, Minneapolis, Minn., USA), CD34 (Beckman Coulter, Fullerton, Calif., USA) and CD133 (Miltenyi Biotech, Auburn, Calif., USA) were performed in selected samples.

Caspase-3 Activation and Cytochrome c

Apoptotic susceptibility of EPCs was assessed by determining intracellular active caspase- 3 concentrations and cytochrome $c$ levels. Activation of caspase- 3 was induced by incubating EPCs with staurosporine for $3 \mathrm{~h}$ at $37^{\circ} \mathrm{C}$. Cells were then modified with biotin-ZVKD-fmk and lysed in extraction buffer. Both active caspase- 3 and cytochrome concentrations were determined by enzyme immunoassay (R\&D Systems). The rationale for using staurosporine to activate caspase- 3 is several fold. Firstly, staurosporine is the most frequently used in vitro stimulus of active caspase-3, regardless of the cell line being studied. Secondly, a major advantage of using staurosporine as an apoptosis inducer is that all of the proteins required to execute staurosporine-induced cell death are constitutively expressed [20, 21]. As a result, important mechanisms of cellular apoptosis have resulted from using staurosporine $[21,22]$. Thirdly, in addition to the reliability, reproducibility and specificity of action of staurosporine, we chose it to allow comparison of our results to other studies involving cellular apoptosis. Finally, staurosporine elicits similar increases in active caspase- 3 compared with ox-LDL $[23,24]$.

\section{Apoptotic Proteins}

EPCs from 10 men (6 young and 4 older) were lysed in cell extraction buffer supplemented with protease inhibitors for determination of proteins in the apoptotic pathway. Proteins $(30 \mu \mathrm{g})$ were separated by SDS-PAGE on a 10.4-14\% gradient gel (BioRad Criterion) and transferred onto a nitrocellulose membrane. Membranes were blocked overnight in $5 \%$ milk protein in phosphate- 
buffered saline with $0.5 \%$ Tween (PBST). Primary and secondary antibodies were diluted in 5\% bovine serum albumin in PBST per manufacturer's suggestions. Membranes were incubated with primary antibodies for $2 \mathrm{~h}$. Thereafter, membranes were thoroughly washed with PBST and incubated with HRP-conjugated secondary antibodies for $2 \mathrm{~h}$. Membranes were then washed with PBST prior to chemiluminescent imaging on a ChemiDoc-It Imaging Sytem (UVP). Membranes were probed for total Akt, total Bad, Bcl-2, Bax, $\beta$-actin, 14-3-3e and p70 S6-kinase.

\section{Telomerase Activity}

A telomeric-repeat amplification protocol assay was used for quantitative analysis of telomerase activity (Telo TAGGG PCR ELISA $^{\text {PLUS; }}$ Roche Molecular Biochemicals) in EPCs from 14 men (6 young and 8 older) as previously described by our laboratory [10].

\section{Statistics}

Group differences were determined by analysis of variance. Relations between variables of interest were assessed by linear and stepwise regression analysis. All data are expressed as mean \pm SEM. Statistical significance was set a priori at $\mathrm{p}<0.05$.

\section{Results}

Subject characteristics are displayed in table 1 . None of the subjects were obese; however, the older men demonstrated significantly higher percentage of body fat, waist circumference and BMI compared with young men. Although within clinically normal ranges, systolic blood pressure, plasma concentrations of total cholesterol, low-density lipoprotein, triglycerides, glucose and insulin were higher in the older men.

There were no significant differences in basal concentrations of intracellular active caspase-3 (0.33 \pm .09 vs. $0.44 \pm 0.07 \mathrm{pg} / \mathrm{ml})$ and cytochrome c $(17.2 \pm 0.7 \mathrm{vs}$. $20.4 \pm 2.5 \mathrm{pg} / \mathrm{ml}$ ) between the young and older men. However, staurosporine-induced intracellular active caspase- 3 concentrations were approximately $35 \%$ higher $(\mathrm{p}<0.05)$ in older $(3.15 \pm 0.29 \mathrm{pg} / \mathrm{ml})$ compared with young $(2.33 \pm 0.24 \mathrm{pg} / \mathrm{ml})$ men (fig. 1$)$. There were no significant correlations between staurosporine-induced activation of caspase- 3 and any of the measured anthropometric, hemodynamic or metabolic variables. Total Akt, p70 S6-kinase and Bcl-2 expression was significantly lower in the older than the young men (fig. 2). There were no age-related differences in the expression of 14-3-3 $\varepsilon$ or Bax between groups (fig. 3). EPC telomerase activity was approximately $60 \%$ lower in older $(0.16$ $\pm 0.08 \mathrm{AU})$ compared with young $(0.49 \pm 0.10 \mathrm{AU})$ men (fig. 4).

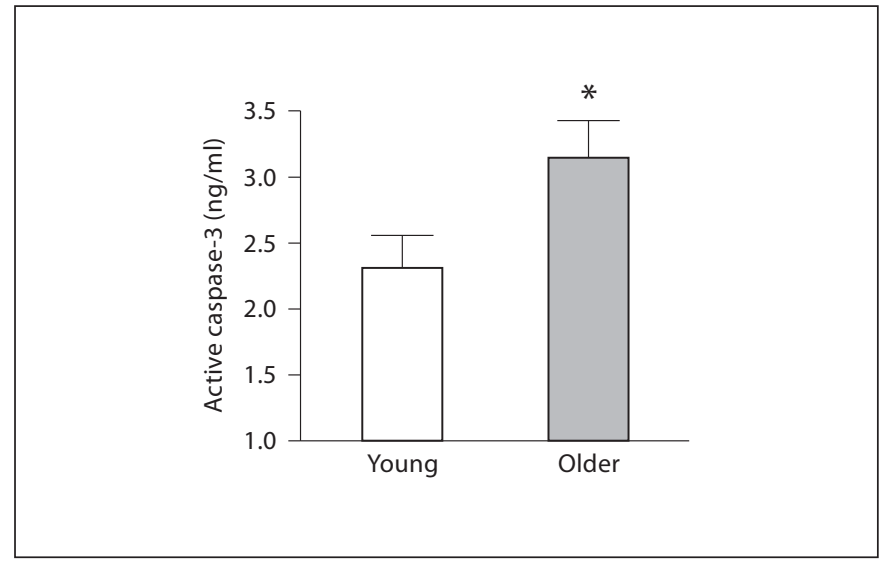

Fig. 1. Intracellular active caspase-3 concentrations in EPCs from young and older men in response to staurosporine stimulation. Values are means \pm SEM. ${ }^{*} \mathrm{p}<0.05$ vs. young men.

Table 1. Selected subject characteristics

\begin{tabular}{lcc}
\hline Variables & $\begin{array}{l}\text { Young } \\
(\mathrm{n}=16)\end{array}$ & $\begin{array}{l}\text { Older } \\
(\mathrm{n}=24)\end{array}$ \\
\hline Age, years & $25 \pm 1$ & $61 \pm 1^{*}$ \\
Body mass, kg & $79.7 \pm 2.2$ & $87.3 \pm 2.5^{*}$ \\
BMI & $24.2 \pm 0.6$ & $27.2 \pm 0.6^{*}$ \\
Body fat, \% & $16.0 \pm 1.2$ & $27.6 \pm 1.3^{*}$ \\
Waist circumference, cm & $84.0 \pm 1.8$ & $96.8 \pm 1.8^{*}$ \\
Systolic BP, mm Hg & $113 \pm 3$ & $127 \pm 2^{*}$ \\
Diastolic BP, mm Hg & $68 \pm 2$ & $78 \pm 1^{*}$ \\
Total cholesterol, mmol/l & $4.2 \pm 0.2$ & $5.2 \pm 0.2^{*}$ \\
LDL cholesterol, mmol/l & $2.5 \pm 0.1$ & $3.3 \pm 0.1^{*}$ \\
HDL cholesterol, mmol/l & $1.3 \pm 0.1$ & $1.2 \pm 0.1$ \\
Triglycerides, mmol/l & $1.0 \pm 0.1$ & $1.4 \pm 0.1^{*}$ \\
Glucose, mmol/l & $4.7 \pm 0.1$ & $5.3 \pm 0.1^{*}$ \\
Insulin, pmol/l & $32.6 \pm 3.1$ & $40.2 \pm 3.9$ \\
\hline
\end{tabular}

$\mathrm{BMI}=$ Body mass index BP = blood pressure LDL = low-density lipoprotein; HDL $=$ high-density lipoprotein. Values are means \pm SEM. ${ }^{*} \mathrm{p}<0.05$ versus young.

\section{Discussion}

The primary new finding of the present study is that aging is associated with an increase in apoptotic susceptibility of EPCs in healthy men. Indeed, EPCs harvested from older healthy men demonstrated greater sensitivity to the proapoptotic stimulus staurosporine marked by significantly greater intracellular active caspase- 3 


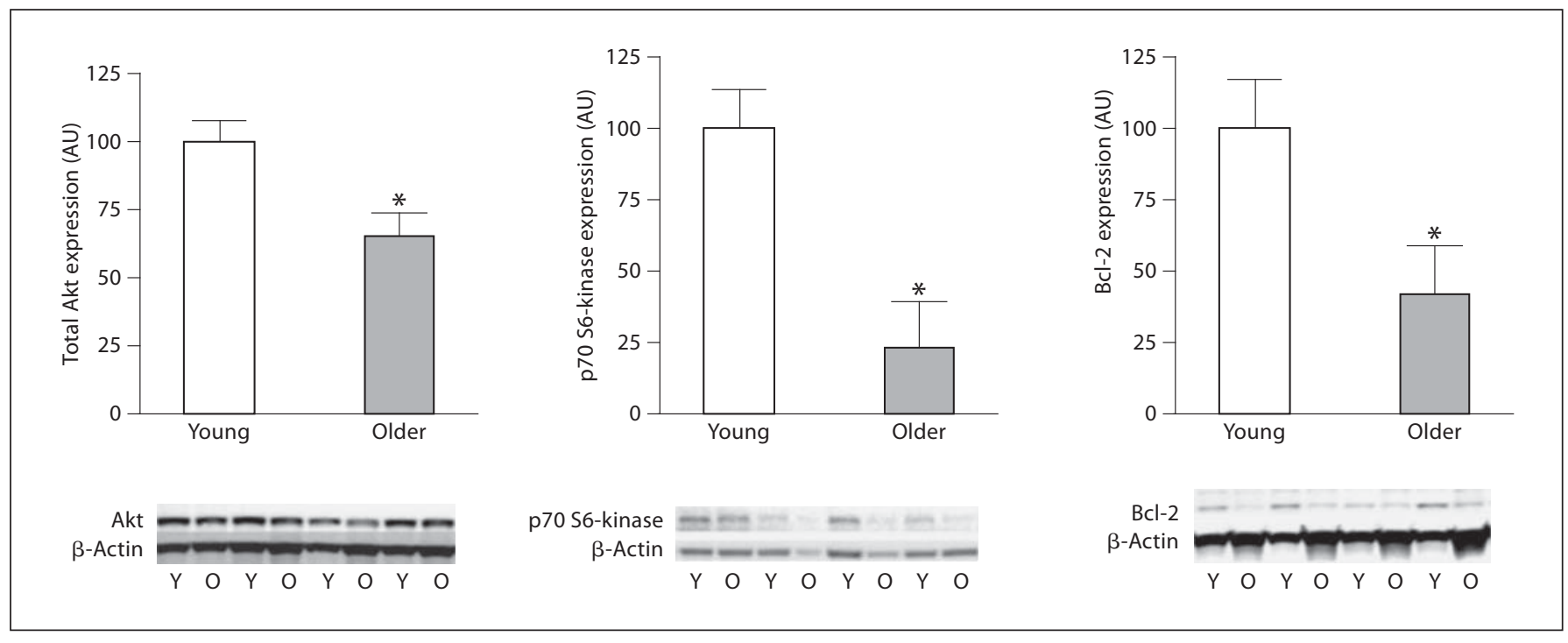

Fig. 2. Akt, p70 S6-kinase and Bcl-2 protein expression in EPCs from young (Y) and older (O) men. Protein abundance is expressed relative to $\beta$-actin to account for variations in protein loading and is shown normalized to the young mean. Values are means \pm SEM. ${ }^{*} \mathrm{p}<0.05$ vs. young men.
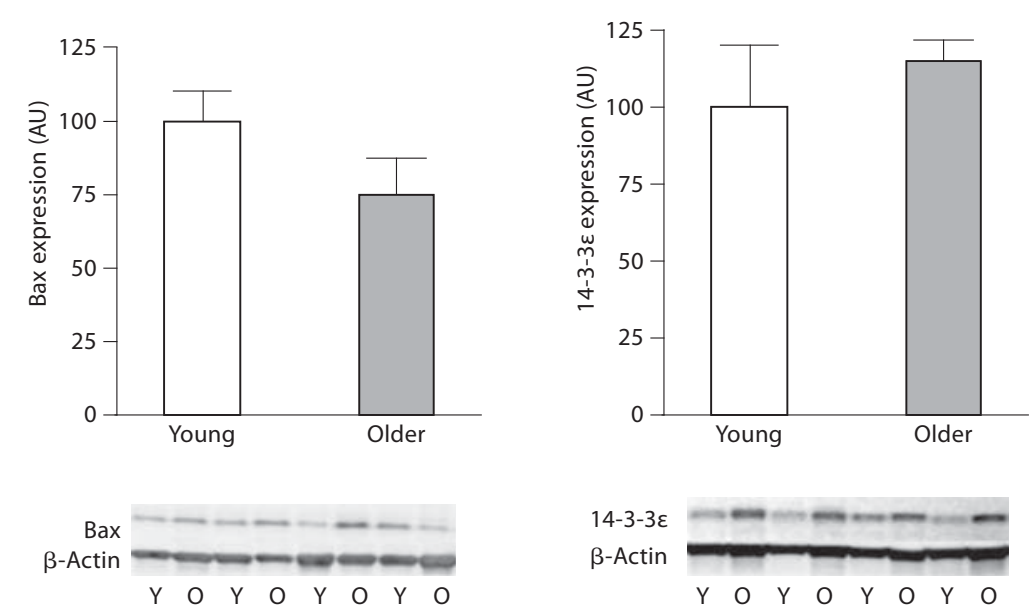

Fig. 3. Bax and 14-3-3e protein expression in EPCs from young $(\mathrm{Y})$ and older $(\mathrm{O})$ men. Protein abundance is expressed relative to $\beta$-actin to account for variations in protein loading and is shown normalized to the young mean. Values are means \pm SEM.

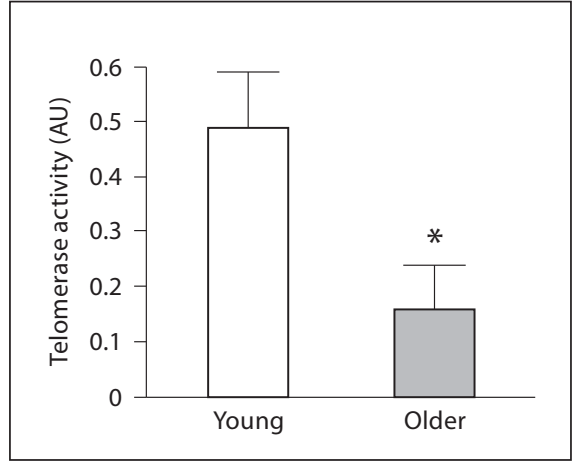

Fig. 4. Telomerase activity in EPCs from young and older men. Values are means \pm SEM. * $\mathrm{p}<0.05$ vs. young men. concentrations compared with EPCs harvested from young men. To our knowledge, we are the first to demonstrate that EPCs from older adult humans have greater apoptotic sensitivity. Additionally, EPCs from older men have unfavorable alterations in the expression of key PI-3-kinase/Akt signaling pathway-associated pro- teins. Specifically, we observed attenuated expression of antiapoptotic proteins Akt, p70 S6-kinase and Bcl-2, as well as reduced telomerase activity. Collectively, these data suggest that aging is associated with a proapoptotic EPC phenotype. 
Intracellular concentrations of active caspase- 3 and cytochrome $\mathrm{c}$ provide biological insight into the apoptotic tendency of a cell. Activation of caspase-3, the so-called 'executioner molecule', initiates a myriad of cysteine-aspartic acid proteases resulting in cellular instability, degradation and death. Functional deficits and impaired viability at both the cell and tissue levels have been related to elevations in proapoptotic signaling [25-27]. Hoffmann et al. [28] reported that aging is linked with enhanced sensitivity towards apoptosis via increased caspase-3 activity and reduced activation of the prosurvival enzyme endothelial nitric oxide synthase. Higami and Shimokama [29] reported that apoptosis signaling programs are elevated in multiple tissue depots (such as neurons, cardiac monocytes and hepatocytes) in aged mammals. The novel finding of the present study is that EPCs harvested from older men demonstrated markedly greater active intracellular caspase- 3 concentrations in response to staurosporine stimulation compared with EPCs from young men. Heightened sensitivity of EPCs towards apoptosis may be one potential mechanism contributing to reduced EPC bioavailability and function with age [18]. Indeed, accelerated apoptosis and enhanced susceptibility to apoptotic factors are thought to underlie numerical and functional impairments in EPCs and contribute to endothelial dysfunction and atherogenesis [30]. Thus, an apoptotic EPC phenotype can limit bioavailability and reparative capacity, ultimately contributing to the increased risk of atherosclerosis and the prolonged and often complicated recovery from acute vascular events in older adults $[18,30]$.

The mechanisms responsible for the apparent proapoptotic EPC phenotype with aging are unclear. Factors such as inflammation and oxidative stress that are known to increase with age may play a role $[31,32]$. Indeed, the pro-inflammatory cytokine C-reactive protein, that generally increases with age, has been shown to induce EPC apoptosis in vitro [33]. To elucidate possible signaling mechanisms that may be responsible for the greater apoptotic susceptibility of EPCs in older adults, we determined the relative expression of several upstream proteins in the PI-3-kinase/Akt signaling pathway known to effect caspase- 3 activation. This pathway plays a vital role in cell survival by initiating downstream activation of antiapoptotic proteins and suppression of cell death signals [34]. Perturbations in PI-3-kinase/Akt signaling may lead to either excessive cell death or a number of disease processes, such as in cancer [34,35]. In the present study, we demonstrated that aging is associated with decreased expression of antiapoptotic proteins involved in the PI-3-kinase/Akt signaling pathway. Specifically, older men had lower Akt, p70 S6-kinase and Bcl-2 expression compared with young men. Previous studies have shown that constitutive activation of Akt and p70 S6-kinase promotes cell survival, while pharmacological inhibition of these proteins increases apoptosis [36]. Similarly, suppression of Bcl-2 expression results in greater cell death in multiple cell types $[37,38]$. Thus, the greater apoptotic susceptibility in EPCs from older men may be due, at least in part, to overall lower expression of antiapoptotic proteins associated with the PI-3-kinase/Akt signaling pathway. In addition, telomerase activity has been shown to be inversely associated with intracellular caspase-3 activation [39]. Considering we observed approximately $60 \%$ less telomerase activity in EPCs from older men compared with younger men, it is possible that age-related reductions in telomerase activity may contribute to enhanced caspase- 3 activation.

A number of experimental considerations regarding the present study should be mentioned. Firstly, there is no clear consensus on what criteria should be used to isolate, culture or quantify EPCs, creating ambiguity when comparing and interpreting investigations. In the present study, we isolated putative EPCs with minimal time spent in culture. These cells demonstrate several endothelial phenotypic characteristics including DiI-ac-LDL uptake, lectin binding and expression of von Willebrand factor, VE-cadherin, VEGFR-2 and CD31 [40, 41]. Additionally, it has been shown that these cells participate in vasculogenesis and repair [5] and are related to both endothelial dysfunction and cardiovascular risk [42, 43]. Other studies involving EPCs have employed different isolation procedures and in vitro conditions, such as expanding cells on culture dishes coated with different extracellular matrix proteins (collagen, gelatin) and exposure to extended endothelial specific in vitro culture conditions (2-4 weeks) [44]. These techniques may yield different results and thus the findings of the present study should be viewed within the context of our isolation, culture and characterization methodology. Secondly, as with all cross-sectional experimental designs, we must acknowledge the possibility that genetic and/or lifestyle behaviors influenced our results. Moreover, numerous pathologic, pharmacologic and physiologic factors have been reported to influence EPC number and function. We attempted to minimize these potential influences by studying strictly screened healthy adults who were free of overt disease, nonmedicated, nonsmokers and not physically active. Thirdly, reduced telomerase activity has been linked to cellular senescence [45, 46]; we did not address the possible influence of age-related senescence on our results. Fourthly, although we observed significant age-related differences in the protein 
expression of Akt, p70 S6-kinase and Bcl-2, we are unable to comment on the activity status of these proteins. Finally, the results reported herein pertain only to men; considering differences in EPC function have been reported between men and women [9] extrapolation of our findings to women should be done with caution.

In summary, both experimental $[47,48]$ and clinical studies $[49,50]$ have shown that EPCs are essential to vascular homeostasis. Their capacity to maintain, repair and/or regenerate the endothelial monolayer and restore functional activity is fundamentally important to prevent atherosclerotic lesion development and thrombus formation [7, 51]. Herein, we demonstrate that EPCs harvested from older men have elevated apoptotic suscepti- bility. Additionally, our results suggest that aging tips the balance between pro- and antiapoptotic signaling proteins to a more proapoptotic EPC state. The proapoptotic phenotype in EPCs harvested from older men may contribute, at least in part, to the age-related decline in EPC number and function observed in this population.

\section{Acknowledgements}

We would like to thank all subjects who participated in the study as well as Yoli Casas for her administrative assistance. This study was supported by National Institutes of Health Awards HL076434, HL077450 and RR00051, and American Heart Association Award 0555678Z.

\section{References}

1 Seals DR, Desouza CA, Donato AJ, Tanaka $\mathrm{H}$ : Habitual exercise and arterial aging. J Appl Physiol 2008;105:1323-1332.

-2 Smith DT, Hoetzer GL, Greiner JJ, Stauffer BL, DeSouza CA: Effects of ageing and regular aerobic exercise on endothelial fibrinolytic capacity in humans. J Physiol 2003;546: 289-298.

-3 Stauffer BL, Westby CM, DeSouza CA: Endothelin-1, aging and hypertension. Curr Opin Cardiol 2008;23:350-355.

4 Quyyumi AA: Circulating endothelial progenitor cells as novel biological determinants of vascular function and risk. Can J Cardiol 2004;20:44B-48B

5 Asahara T, Masuda H, Takahashi T, Kalka C, Pastore C, Silver M, Kearne M, Magner M, Isner JM: Bone marrow origin of endothelial progenitor cells responsible for postnatal vasculogenesis in physiological and pathological neovascularization. Circ Res 1999;85: 221-228.

6 Chavakis E, Hain A, Vinci M, Carmona G, Bianchi ME, Vajkoczy P, Zeiher AM, Chavakis T, Dimmeler S: High-mobility group box 1 activates integrin-dependent homing of endothelial progenitor cells. Circ Res 2007; 100:204-212.

7 Urbich C, Dernbach E, Rossig L, Zeiher AM, Dimmeler S: High glucose reduces cathepsin 1 activity and impairs invasion of circulating progenitor cells. J Mol Cell Cardiol 2008;45: 429-436.

$\checkmark 8$ Reyes M, Dudek A, Jahagirdar B, Koodie L, Marker PH, Verfaillie CM: Origin of endothelial progenitors in human postnatal bone marrow. J Clin Invest 2002;109:337-346.

9 Hoetzer GL, Van Guilder GP, Irmiger HM, Keith RS, Stauffer BL, DeSouza CA: Aging, exercise, and endothelial progenitor cell clonogenic and migratory capacity in men. J Appl Physiol 2007;102:847-852.
10 Kushner EJ, Van Guilder GP, Maceneaney OJ, Cech JN, Stauffer BL, DeSouza CA: Aging and endothelial progenitor cell telomere length in healthy men. Clin Chem Lab Med 2009;47:47-50.

11 Junhui Z, Xingxiang W, Guosheng F, Yunpeng S, Furong Z, Junzhu C: Reduced number and activity of circulating endothelial progenitor cells in patients with idiopathic pulmonary arterial hypertension. Respir Med 2008;102:1073-1079.

12 Vasa M, Fichtlscherer S, Aicher A, Adler K, Urbich C, Martin H, Zeiher AM, Dimmeler S: Number and migratory activity of circulating endothelial progenitor cells inversely correlate with risk factors for coronary artery disease. Circ Res 2001;89:E1-E7.

13 Danial NN, Korsmeyer SJ: Cell death: critical control points. Cell 2004;116:205-219.

14 Thompson CB: Apoptosis in the pathogenesis and treatment of disease. Science 1995 267:1456-1462.

15 Kluck RM, Bossy-Wetzel E, Green DR, Newmeyer DD: The release of cytochrome $\mathrm{c}$ from mitochondria: A primary site for bcl-2 regulation of apoptosis. Science 1997;275:11321136.

16 Cohen GM: Caspases: the executioners of apoptosis. Biochem J 1997;326:1-16.

17 Bermudez Y, Erasso D, Johnson NC, Alfonso MY, Lowell NE, Kruk PA: Telomerase confers resistance to caspase-mediated apoptosis. Clin Interv Aging 2006;1:155-167.

18 Rauscher FM, Goldschmidt-Clermont PJ, Davis BH, Wang T, Gregg D, Ramaswami P, Pippen AM, Annex BH, Dong C, Taylor DA: Aging, progenitor cell exhaustion, and atherosclerosis. Circulation 2003;108:457-463.
19 Thum T, Hoeber S, Froese S, Klink I, Stichtenoth DO, Galuppo P, Jakob M, Tsikas D, Anker SD, Poole-Wilson PA, Borlak J, Ertl G, Bauersachs J: Age-dependent impairment of endothelial progenitor cells is corrected by growth-hormone-mediated increase of insulin-like growth-factor-1. Circ Res 2007;100: 434-443.

20 Weil M, Jacobson MD, Coles HS, Davies TJ, Gardner RL, Raff KD, Raff MC: Constitutive expression of the machinery for programmed cell death. J Cell Biol 1996;133:1053-1059.

$>21$ Yue TL, Wang C, Romanic AM, Kikly K, Keller P, DeWolf WE Jr, Hart TK, Thomas HC, Storer B, Gu JL, Wang X, Feuerstein GZ: Staurosporine-induced apoptosis in cardiomyocytes: a potential role of caspase-3. J Mol Cell Cardiol 1998;30:495-507.

22 Xia Z, Dickens M, Raingeaud J, Davis RJ, Greenberg ME: Opposing effects of erk and jnk-p38 map kinases on apoptosis. Science 1995;270:1326-1331.

-23 Hutter R, Valdiviezo C, Sauter BV, Savontaus M, Chereshnev I, Carrick FE, Bauriedel G, Luderitz B, Fallon JT, Fuster V, Badimon JJ: Caspase- 3 and tissue factor expression in lipid-rich plaque macrophages: evidence for apoptosis as link between inflammation and atherothrombosis. Circulation 2004;109: 2001-2008.

24 Reeve JL, Stenson-Cox C, O’Doherty A, Porn-Ares I, Ares M, O'Brien T, Samali A: OxLDL-induced gene expression patterns in CASMC are mimicked in apoE-/- mice aortas. Biochem Biophys Res Commun 2007; 356:681-686.

25 Hale AJ, Smith CA, Sutherland LC, Stoneman VE, Longthorne V, Culhane AC, Williams GT: Apoptosis: molecular regulation of cell death. Eur J Biochem 1996;237:884. 
26 Kroemer G, Dallaporta B, Resche-Rigon M: The mitochondrial death/life regulator in apoptosis and necrosis. Annu Rev Physiol 1998;60:619-642.

-27 Olivetti G, Abbi R, Quaini F, Kajstura J, Cheng W, Nitahara JA, Quaini E, Di Loreto C, Beltrami CA, Krajewski S, Reed JC, Anversa $\mathrm{P}$ : Apoptosis in the failing human heart. N Engl J Med 1997;336:1131-1141.

-28 Hoffmann J, Haendeler J, Aicher A, Rossig L, Vasa M, Zeiher AM, Dimmeler S: Aging enhances the sensitivity of endothelial cells toward apoptotic stimuli: Important role of nitric oxide. Circ Res 2001;89:709-715.

29 Higami Y, Shimokawa I: Apoptosis in the aging process. Cell Tissue Res 2000;301:125132.

30 Dimmeler S, Zeiher AM: Vascular repair by circulating endothelial progenitor cells: the missing link in atherosclerosis? J Mol Med 2004;82:671-677.

-31 Cadenas E, Davies KJ: Mitochondrial free radical generation, oxidative stress, and aging. Free Radic Biol Med 2000;29:222-230.

$\checkmark 32$ Chung HY, Cesari M, Anton S, Marzetti E, Giovannini S, Seo AY, Carter C, Yu BP, Leeuwenburgh C: Molecular inflammation: underpinnings of aging and age-related diseases. Ageing Res Rev 2009;8:18-30.

33 Verma S, Kuliszewski MA, Li SH, Szmitko PE, Zucco L, Wang CH, Badiwala MV, Mickle DA, Weisel RD, Fedak PW, Stewart DJ, Kutryk MJ: C-reactive protein attenuates endothelial progenitor cell survival, differentiation, and function: further evidence of a mechanistic link between c-reactive protein and cardiovascular disease. Circulation 2004;109:2058-2067.

-34 Datta SR, Dudek H, Tao X, Masters S, Fu H, Gotoh Y, Greenberg ME: Akt phosphorylation of bad couples survival signals to the cell-intrinsic death machinery. Cell 1997;91: 231-241.

-35 Cantley LC, Neel BG: New insights into tumor suppression: PTEN suppresses tumor formation by restraining the phosphoinositide 3-kinase/AKT pathway. Proc Natl Acad Sci USA 1999;96:4240-4245.
36 Brognard J, Clark AS, Ni Y, Dennis PA: Akt/ protein kinase $\mathrm{B}$ is constitutively active in non-small cell lung cancer cells and promotes cellular survival and resistance to chemotherapy and radiation. Cancer Res 2001; 61:3986-3997.

37 Matsushita H, Morishita R, Nata T, Aoki M, Nakagami H, Taniyama Y, Yamamoto K, Higaki J, Yasufumi K, Ogihara T: Hypoxiainduced endothelial apoptosis through nuclear factor- $\kappa \mathrm{B}(\mathrm{NF}-\kappa \mathrm{B})$-mediated bcl-2 suppression: In vivo evidence of the importance of NF- $\kappa \mathrm{B}$ in endothelial cell regulation. Circ Res 2000;86:974-981.

38 Takahashi M, Saito H, Okuyama T, Miyashita T, Kosuga M, Sumisa F, Yamada M, Ebinuma H, Ishii H: Overexpression of bcl-2 protects human hepatoma cells from fas-antibody-mediated apoptosis. J Hepatol 1999; 31:315-322.

39 Dong XX, Hui ZJ, Xiang WX, Rong ZF, Jian S, Zhu CJ: Ginkgo biloba extract reduces endothelial progenitor-cell senescence through augmentation of telomerase activity. J Cardiovasc Pharmacol 2007;49:111-115.

40 Hur J, Yang HM, Yoon CH, Lee CS, Park KW, Kim JH, Kim TY, Kim JY, Kang HJ, Chae IH, Oh BH, Park YB, Kim HS: Identification of a novel role of $t$ cells in postnatal vasculogenesis: characterization of endothelial progenitor cell colonies. Circulation 2007;116:16711682 .

41 Ito T, Ishida F, Shimodaira S, Kitano K: Polymorphisms of platelet membrane glycoprotein Ib $\alpha$ and plasma von Willebrand factor antigen in coronary artery disease. Int $\mathrm{J} \mathrm{He}$ matol 1999;70:47-51.

42 Hill JM, Zalos G, Halcox JP, Schenke WH, Waclawiw MA, Quyyumi AA, Finkel T: Circulating endothelial progenitor cells, vascular function, and cardiovascular risk. N Engl J Med 2003;348:593-600.

43 Werner C, Hanhoun M, Widmann T, Kazakov A, Semenov A, Poss J, Bauersachs J, Thum T, Pfreundschuh M, Muller P, Haendeler J, Bohm M, Laufs U: Effects of physical exercise on myocardial telomereregulating proteins, survival pathways, and apoptosis. J Am Coll Cardiol 2008;52:470482.
44 Timmermans F, Plum J, Yoder MC, Ingram DA, Vandekerckhove B, Case J: Endothelial progenitor cells: Identity defined? J Cell Mol Med 2009; 13:87-102.

45 Vasa M, Breitschopf K, Zeiher AM, Dimmeler S: Nitric oxide activates telomerase and delays endothelial cell senescence. Circ Res 2000;87:540-542.

46 Yang J, Chang E, Cherry AM, Bangs CD, Oei Y, Bodnar A, Bronstein A, Chiu CP, Herron GS: Human endothelial cell life extension by telomerase expression. J Biol Chem 1999;274: 26141-26148.

-47 Kawamoto A, Gwon HC, Iwaguro H, Yamaguchi JI, Uchida S, Masuda H, Silver M, Ma H, Kearney M, Isner JM, Asahara T: Therapeutic potential of ex vivo expanded endothelial progenitor cells for myocardial ischemia. Circulation 2001;103:634-637.

48 Kocher AA, Schuster MD, Szabolcs MJ, Takuma S, Burkhoff D, Wang J, Homma S, Edwards NM, Itescu S: Neovascularization of ischemic myocardium by human bone-marrow-derived angioblasts prevents cardiomyocyte apoptosis, reduces remodeling and improves cardiac function. Nat Med 2001;7: 430-436.

49 Assmus B, Schachinger V, Teupe C, Britten M, Lehmann R, Dobert N, Grunwald F, Aicher A, Urbich C, Martin H, Hoelzer D, Dimmeler S, Zeiher AM: Transplantation of progenitor cells and regeneration enhancement in acute myocardial infarction (TOPCARE-AMI). Circulation 2002;106:30093017.

50 Strauer BE, Brehm M, Zeus T, Kostering M, Hernandez A, Sorg RV, Kogler G, Wernet P: Repair of infarcted myocardium by autologous intracoronary mononuclear bone marrow cell transplantation in humans. Circulation 2002;106:1913-1918.

51 Dzau VJ, Gnecchi M, Pachori AS, Morello F, Melo LG: Therapeutic potential of endothelial progenitor cells in cardiovascular diseases. Hypertension 2005;46:7-18. 